\title{
The Effect of Company Size (SIZE), Leverage, Independent Board of Commissioners, and Profitability on Corporate Social Responsibility Disclosure (Empirical Study on Mining Companies Listed on the Indonesia Stock Exchange (IDX) for the 2012-2016 Period)
}

\author{
Lawe Anasta Sabarudin Muslim \\ Economics Faculty, Universitas Mercu Buana
}

\begin{abstract}
This study aims to determine the effect of Company Size, Leverage, Independent Board of Commissioners, and Profitability on Disclosure of Corporate Social Responsibility. The sample in this study were 9 Mining Companies listed on the Indonesia Stock Exchange (IDX) for the period 2012-2016. This study used multiple linear regression analysis to test the effect of Company Size, Leverage, Independent Board of Commissioners, and Profitability on Corporate Social Responsibility Disclosures. The results of this study indicate that Company Size and Leverage have a positive effect while the Independent Board of Commissioners and Profitability have a negative effect on disclosure of Corporate Social Responsibility.
\end{abstract}

Keywords: Company Size, Leverage, Independent Board of Commissioners, Profitability, Corporate Social Responsibility.

DOI: $10.7176 / \mathrm{JESD} / 10-20-05$

Publication date:October $31^{\text {st }} 2019$

\section{INTRODUCTION}

The history of accounting that is growing rapidly causes accounting reporting to be used more as a tool of accountability to the owners of capital so that the company's orientation is more focused on the owners of capital. On the other hand, if viewed from an economic standpoint, the main goal of the company is to get maximum profits so that companies often ignore social and environmental impacts that occur on economic actions carried out where such actions can cause environmental damage, such as deforestation, air pollution, pollution water, and so on (Santioso and Chandra, 2012).

Corporate Social Responsibility is intended to encourage the business world to be more ethical in carrying out its activities so as not to affect or adversely affect society and the environment. The CSR concept became known since the early 1970s which was generally interpreted as a collection of policies and practices related to stakeholders, values, fulfillment of legal provisions, community and environmental awards, as well as business commitments to contribute to sustainable development.

Corporate Social Responsibility is an accounting concept that can bring companies to carry out their responsibilities to the environment and society. Corporate Social Responsibility arises as a result of the existence of companies whose activities in addition to providing many benefits but causing many negative impacts. The negative impact was felt by the surrounding community who were close to the company. According to the World Business Council for Sustainable Development, social responsibility activities (CSR) is a continuing commitment by the business community to act ethically and contribute to the economic development of the local community or society at large, along with the improvement in the standard of living of workers and their entire family.

Environmental damage in Indonesia due to mining operations reached $70 \%$. In Indonesia, the practice of Corporate Social Responsibility has received considerable attention. This is motivated by various cases such as deforestation, increased pollution and waste, poor quality and security of companies, excessive exploitation of natural resources, misuse of investment and others. This shows that this is a reflection that in essence the company only prioritizes profits as the main factor of its operational activities without regard to the negative impacts caused by company activities that harm others. In this case, the role of Corporate Social Responsibility plays an important role in maintaining and preserving the social environment which is an obligation for every company to continue to pay attention to the quality of the environment in which the company is located.

Corporate social responsibility is regulated in Article 74 paragraph 1 of Law No. 40 of 2007 concerning Limited Liability Company article 74 and article 66 paragraph (2) points c. Article 74 states that a company carrying out its business activities in and / or related to natural resources must carry out social and environmental responsibilities. If the practice of social and environmental responsibility is not implemented, sanctions will be imposed in accordance with the provisions of the legislation. Company size is a scale that determines the size or size of a company. Measurements that show the size of the company include, total sales, average sales levels, and total assets. For company size, (Sha, 2014) states that positive firm size has a significant effect on disclosure of 
Corporate Social Responsibility. Leverage is a comparison between funds obtained from external companies and funds owned by the company. Leverage also illustrates the capital structure owned by the company, so it can be seen the level of uncollectible risk of a debt.

While the Board of Commissioners' Size is part of the company in accordance with the theory of Corporate Governance with its main function paying attention in a responsible manner for good corporate governance in order to achieve the objectives of the company and shareholders. According to (Sudarmadji and Sularto, 2007 in Esty, 2016) profitability is a performance indicator carried out by management in managing corporate wealth as indicated by profits generated. Broadly speaking, the profits generated by the company come from sales and investments made by the company. So one of the company's goals, which is to achieve profits, will be able to improve the welfare of shareholders. With high profitability, it will provide more opportunities for management to disclose and carry out their CSR programs.

\section{FORMULATION OF THE PROBLEM}

Based on the description, the author formulates the problems to be examined as follows:

1. Does the size of the company affect the disclosure of Corporate Social Responsibility?

2. Does leverage affect the disclosure of Corporate Social Responsibility?

3. Does the Independent Board of Commissioners influence the disclosure of Corporate Social Responsibility?

4. Does profitability affect the disclosure of Corporate Social Responsibility?

\section{RESEARCH PURPOSE}

The purpose of this study is:

a. To know the effect of company size (Size) on disclosure of Corporate Social Responsibility.

b. To know the effect of Leverage on disclosure of Corporate Social Responsibility.

c. To know the influence of the Independent Board of Commissioners on disclosure of Corporate Social Responsibility.

d. To know the effect of Profitability on disclosure of Corporate Social Responsibility.

\section{LITERATURE REVIEW, LOGICAL FRAMEWORK, HYPOTHESIS}

Stakeholder Theory :Stakeholders are all parties, both internal and external, who have relationships that are both influential and influenced, directly or indirectly by the company. Thus, stakeholders are internal and external parties, such as the government, competing companies, investors, communities, the environment, employees, institutions outside the company and others whose conditions greatly influence and are influenced by the company (Hadi 2011: 93).

Legitimacy Theory

Community legitimacy is a strategic factor for companies to develop the company in the future. That, can be used as a vehicle for constructing the company's strategy, especially related to efforts to position themselves amid an increasingly advanced community environment (Hadi, 2011: 87).

Agency theory (Agency Theory)

Agency theory appears to overcome agency conflicts that can occur in agency relationships, the separation of ownership by principals and control by agents in an organization tends to cause conflict between principal and agent. The principal is the shareholder or investor while the agent is the management that manages the company consisting of the board of commissioners and the board of directors.

Corporate Social Responsibility

The concept of corporate social responsibility was first put forward by Howard R. Bowen in 1953. The development of the concept of Corporate Social Responsibility that took place over the past fifty years has changed the orientation of CSR. If initially CSR activities are based more on philanthropic activities, then CSR has been made as one of the strategies used by companies to improve the company's image which will also influence the financial performance of the company.

Disclosure of Corporate Social Responsibility

The disclosure of corporate social responsibility (Corporate Social Responsibility) is the process of communicating the social and environmental impacts of a company's economic activities towards certain groups in the community as a whole. The company's negative contribution to the surrounding environment has caused a loss of public trust, therefore disclosing information about the company's operations in relation to the environment as a corporate responsibility is expected to restore public trust.

CSRI INDEX = Principles of Corporate Social Responsibility

The real of social responsibility (Corporate Social Responsibility) contains very broad and complex dimensions. Besides that, social responsibility also contains very different interpretations, especially related to stakeholders. (Crowther, 2008) divides the three principles of social responsibility, namelySustainability, related to how the 
company conducts its activities about calculating the sustainability of resources in the future.

1. Accountability, is the company's effort to be open and responsible for the activities that have been

2. ransparency, which is an important principle for external parties. This principle has a role in reducing information asymmetry, misunderstanding, especially information and accountability for various environmental impacts.

Factors Affecting CSR Disclosures

a. Company Size

Company size can influence the extent of disclosure of information in the company's financial statements. In general it can be said that large companies will disclose more information than small companies. In general it can be said that large companies will disclose more information than small companies.

Measurements that show the size of the company can be seen from the amount of income, total assets, number of employees and total capital will reflect the condition of the company that is getting stronger. The size of the company is the size or size of assets owned by the company. Basically the size of the company is only divided into three categories, namely large companies, medium-sized companies, and small companies (Pradipta and Purwaningsih, 2012: 12).)

b. Leverage

Leverage describes the extent to which owner's capital can cover debts to parties outside the company. Leverage is a measure of the amount of assets financed by debt that is used to finance assets originating from outside parties (creditors) with the ability of companies financed by capital (Harahap and Sofyan, 2007). Companies that have a lower level of leverage more finance their assets with their own capital. Whereas a company that has high leverage means that it relies heavily on external loans to finance its assets. The higher the level of corporate leverage, the manager will strive to report higher current profits than future profits. In order for reported earnings to be high, managers must reduce costs including the costs of disclosing social information. Formula:

c. Independent Board of Commissioners

An independent commissioner is a commissioner who does not originate from a party that has a good business relationship with family relations with the company (FCGI, 1001). An independent commissioner is another member of the board of commissioners, a controlling shareholder, and is free from business relationships or other relationships that can affect the ability to act independently in the interests of the company (KNKG, 2006). The board of commissioners is the highest internal control mechanism that is responsible for monitoring the actions of top management. The Independent Board of Commissioners has the authority to supervise and provide instructions and direction to the company management. With the authority they have, an independent board of commissioners can have a strong enough influence to pressure management to disclose corporate social responsibility. Formula: d. Profitability

Measures of profitability can be assessed from operating income, net income, return on investment / assets and return on owner's equity. Profitability is the ability of a company to earn profits in relation to sales, total assets, and equity. so that it can increase the company's shareholder value.

Profitability ratios are used to measure overall management effectiveness aimed at the level of profits obtained in relation to sales and investment. The better the profitability ratio, the better the ability to describe the company's high profitability. The advantage that is worth sharing with shareholders is the profit after interest and tax, the greater the profit gained, the greater the company's ability to pay dividends.

Effect of Company Size on Disclosure of Corporate Social Responsibility

Company size can be the basis for disclosure of corporate social responsibility. This is because large will reveal more information because large companies have greater resources and social responsibility to the community. Large companies are able to make wider disclosures, because they have greater resources.

This theory is supported by research (Sha, 2014) and (Dewi and Priyadi, 2013), then (Santioso and Chandra, 2012) states that positive firm size has a significant effect on disclosure of Corporate Social Responsibility.

Effect of Leverage on Disclosure of Corporate Social Responsibility

Leverage is a tool used to measure how much the company has a risk level of uncollectible debt to creditors who will later be used to finance company assets.(Subiantoro and Mildawati, 2015), (Dewi and keni, 2012), and (Santioso and Chandra, 2012) state that leverage has a positive and insignificant effect on disclosure of the Corporate Social Responsibility of the Company.

Effect of the Independent Board of Commissioners on Disclosure of Corporate Social Responsibility

The board of commissioners can have a strong influence to pressure management to disclose Corporate Social Responsibility. So that the company. A person who has a larger size of the board of commissioners will express more Corporate Social Responsibility.

For the board of commissioners, (Santioso and Chandra, 2012), (Oktarina, (2013) and (Subiantoro and Mildawati, 2015) stated that the independent board of commissioners had a significant positive effect on disclosure of corporate social responsibility.

Effect of Profitability on Disclosure of Corporate Social Responsibility 
According to (Sudarmadjo and Sularto, 2007 in Esty, 2016) profitability is a performance indicator carried out by management in managing corporate wealth as indicated by profits generated. Broadly speaking, the profits generated by the company come from sales and investments made by the company. So one of the company's goals, which is to achieve profits, will be able to improve the welfare of shareholders. This research is supported by (Sha, 2014), (Santioso and Chandra, 2012), then (Rohmah, 2015) stating that profitability has a significant positive effect. Based on the above thinking framework, the conceptual model can be described as follows:

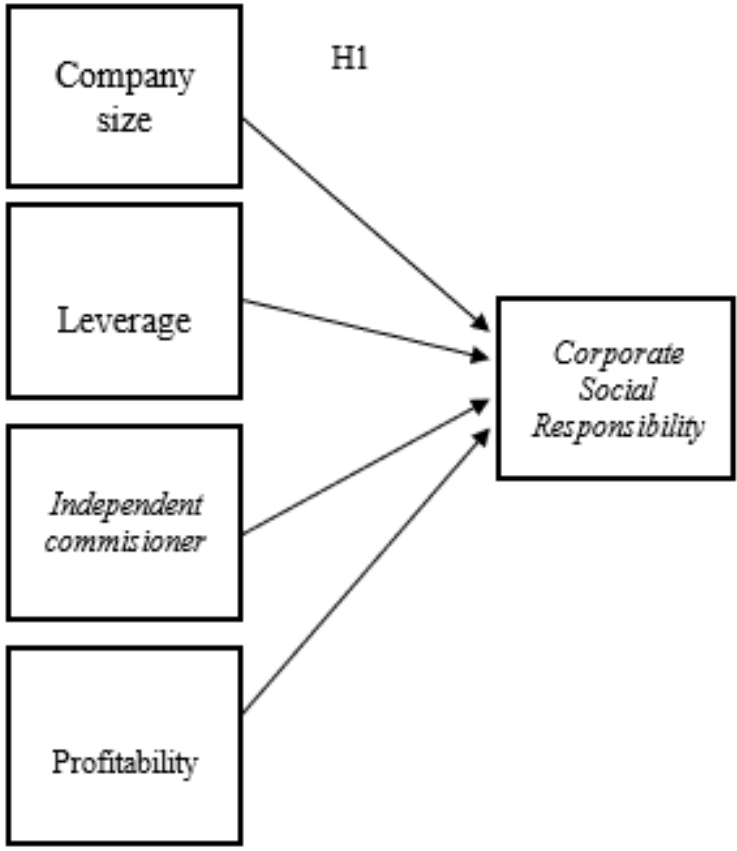

\section{Hipotesis}

By referring to the picture above, we can draw the hypothesis in this study:

H1:Company size has a positive effect on corporate social responsibility

$\mathrm{H} 2$ :Leverage has a positive effect on corporate social responsibility.

H3: The Independent Board of Commissioners has a positive effect on corporate social responsibility.

H4: Profitability has a positive effect on corporate social responsibility.

\section{RESEARCH METODOLOGY}

This research conduct on 2017 towards Mining Companies listed on the Indonesia Stock Exchange (IDX) by taking financial report data through the official website www.idx.co.id in the sample companies in the period 20122016.

Research design

This study uses the results of Statistical Package For The Social Science (SPSS) version 21. The research method used by the writer is a causal method, namely the method used to determine the relationship between independent variables (Size), Size, Leverage, Board Independent Commissioner and Profitability with the dependent variable (dependent variable), namely Corporate Social Responsibility.

Data collection technique

The sample selection method in this study was carried out using archival data collection techniques, namely the use of data originating from existing documents by downloading the annual report of mining sector companies listed on the Indonesia Stock Exchange (IDX) during the study period, namely the 2012 period - 2016 through its official website http://www.idx.co.id and supporting sites http://www.sahamok.com and various kinds of literature that exist. Data analysis method In this study the analysis used was using multiple linear regression analysis, classical assumption test and hypothesis test.

\section{RESULTS AND DISCUSSION}

Test Descriptive StatisticsCorporate Social Responsibility (CSR) has a minimum value of 0.088, namely PT Citatah Tbk in 2012 and a maximum value of 0.648 at PT Elnusa Tbk in 2012, and a mean of 0.23998 and a standard deviation of 0.140467 .

The Company size has a minimum value of 25,784, namely PT Perdana Karya Perkasa Tbk in 2016 and a maximum value of 32,233 to PT Cakra Mineral Tbk in 2014. The mean is 27.78678 and the Standard Deviation is 1.177087 . 
Leverage has a minimum value of 0.007 , namely PT Cakra Minera Tbk in 2014 and a maximum value of 0.795 in PT Radiant Utama Interinsco Tbk in 2014 and a mean of 0.41280 and a standard deviation of 0.251207.

The Independent Board of Commissioners has a minimum value of 0.200 and a maximum value of 0.500 . And the mean is 0.37611 and the standard deviation is 0.086148 .

Profitability has a minimum value of 0.001 , namely PT Cakra Minera Tbk in 2013 and a maximum value of 0.784 in PT Mitra Investindo Tbk in 2015 and a mean of 0.07416 and a standard deviation of 0.128980.

Classic assumption test

a. Normality test Normality Test Results

The normality test aims to test whether in the regression model, the residual variable has a normal distribution. A good regression model is one that has normal or near-normal data distribution. The normality test was carried out by the Kolmogorov-Smirnov Test One Sample. If asymp. Sig (2tailed) above the significance level of $0.05(5 \%)$ means that the variables have a normal distribution (Ghozali, 2016: 30).

The explanation of the normality test shows that the basis for decision making is if Asymp. Sig 2-tailed $>0.05$ or 5\%, the regression model meets the assumptions of normality. The results of the One Sample KolmogorovSmirnov test show the Kolmogorov-Smirnov value of 0.570 and a significant probability level of 0.902 . Because the value of P (Asymp. Sig. 2-tailed) is greater than the 0.05 level of significance $(0.902>0.05)$, it can be concluded that the residual data in this regression model is normally distributed. In other words the regression model used meets the assumptions of normality.

One-Sample

\section{b. Multikolinieritas Test}

\begin{tabular}{|c|c|c|c|c|c|c|}
\hline & & & oefficients ${ }^{\mathrm{a}}$ & & & \\
\hline & & Unstandardi & oefficients & & $\mathrm{t}$ & Sig. \\
\hline & & $\mathrm{B}$ & Std. Error & Beta & & \\
\hline & (Constant) & -17.852 & 13.260 & & -1.346 & .186 \\
\hline & SIZE & .293 & .488 & .112 & .601 & .551 \\
\hline 1 & DER & 2.289 & 2.381 & .182 & .961 & .342 \\
\hline & IND.COMM & 1.821 & 7.862 & .050 & .232 & .818 \\
\hline & ROA & 2.538 & 4.199 & .106 & .605 & .549 \\
\hline
\end{tabular}

a. Dependent Variable: CSR

Sumber : Data diolah dengan SPSS 21

The multicollinearity test aims to test whether the regression model is found to have correlation between independent variables. A good regression model should not have a correlation between independent variables. Multicollinearity test can be done by looking at the tolerance value and variance inflation factor (VIF). The model is declared free from multicolonity disorders if the tolerance value is above 0.10 and the VIF value is below 10 (Ghozali, 2016: 103). The results of the explanation of the multiculturality test show that there is no symptom of multicolonity between independent variables which is indicated by the tolerance value of each variable greater than 0.10 and the Variance Inflation Factor (VIF) value smaller than 10.

b. Heterocedasticity Test Results

Heteroscedasticity test aims to test whether in the regression model there is an inequality of variance from the residual one observation to another observation. A good regression model is the Homoscedasticity (variance from residuals, one observation to another observation remains) or there is no heteroscedasticity. One way that is used to detect the presence or absence of heteroscedasticity is to use the Glejser test where Glejser proposes to reset the absolute value of the residual to the independent variable. If the statistically significant independent variables influence the dependent variable, there is an indication of heteroscedasticity. Table 4.12 shows the results of heteroscedasticity tests

TABEL 4.12

UJI HETEROSKEDASTISITAS

\begin{tabular}{|c|c|c|c|c|c|}
\hline \multirow[t]{2}{*}{ Model } & \multicolumn{2}{|c|}{ Unstandardized Coefficients } & \multirow{2}{*}{$\begin{array}{c}\begin{array}{c}\text { Standardized } \\
\text { Coefficients }\end{array} \\
\text { Beta } \\
\end{array}$} & \multirow[t]{2}{*}{$\mathrm{t}$} & \multirow[t]{2}{*}{ Sig. } \\
\hline & B & Std. Error & & & \\
\hline (Constant) & 499 & ,423 & & 1,180 & 241 \\
\hline Kepercayaan &,- 003 & ,071 &,- 005 &,- 047 & ,963 \\
\hline Wajib Pajak & & & & & \\
\hline Pandangan & ,006 & ,084 & ,007 & 070 & 944 \\
\hline Sosial & & & & & \\
\hline Masyarakat & & & & & \\
\hline
\end{tabular}

Based on Table 4.12, it is known that none of the independent variables statistically significant affect the dependent variable of Unstandardized Absolute Value (AbsUt). This can be seen from the probability of significance above the $5 \%$ confidence level, where for the trust variable has a significance of 0.963 the social view 
variable has a significance of 0.944 . So it can be concluded that the regression model does not contain any heteroscedasticity.

Model Compatibility Test Results

Test the Hypothesia. Significant Test of Individual Parameters (T Test) TABEL 4.16 UJI SIGNIFIKANSI PARAMETER INDIVIDUAL (UJI STATISTIK T)

\begin{tabular}{|c|c|c|c|c|c|c|}
\hline \multirow{2}{*}{\multicolumn{2}{|c|}{ Model }} & \multicolumn{2}{|c|}{$\begin{array}{l}\text { Unstandardized } \\
\text { Coefficients }\end{array}$} & \multirow{2}{*}{$\begin{array}{c}\text { Standardized } \\
\text { Coefficients }\end{array}$} & \multirow[t]{2}{*}{$\mathrm{t}$} & \multirow[t]{2}{*}{ Sig. } \\
\hline & & $B$ & Std. Error & & & \\
\hline \multirow{5}{*}{1} & (Constant) & 1,511 & ,818 & & 1,847 &, 000 \\
\hline & Kepercayaan & 124 & 137 & 091 & ,907 & ,010 \\
\hline & Wajib Pajak & & & & & \\
\hline & Pandangan Sosial & 260 & 162 & 160 & 1,601 & ,012 \\
\hline & Masyarakat & & & & & \\
\hline
\end{tabular}

Based on Table 4.16, it can be seen the regression equation for the influence of trust in government, and social views on the practice of tax evasion as follows:

$\mathrm{Y}=1,511-0,124 \mathrm{X} 1+0,260 \mathrm{X} 2+\mathrm{e}$

WhereY $=$ Tax evasion practices

$\mathrm{X} 1=$ Trust in the government

$\mathrm{X} 2=$ Social views

$\mathrm{e}=$ Error tolerated

\section{Discussion}

Based on the description above, the discussion of the results of the study on the Effect of Trust in the Government and Social Views on Practice The normality test aims to test whether in the regression model, the residual confounding variable has a normal distribution. To test whether the data has a normal distribution or not is to use Kolmogorov Semirnov. Data that is normally distributed is data that has a significance number $>5 \%$ (asymp sig $>$ $5 \%$ ) then the regression model meets the assumptions of normality. The following table 4.10 shows the results of the normality test. Tax Evasion is as follows:

Influence of the Effect of Trust in the Government on Tax Evasion Practices.

Based on the research that has been done in Kebayoran Lama Market, the variable level of trust in the government has a significant level of 0.010 which means that the level of trust in the government has an effect on the practice of tax evasion because of the significant level of trust in the government. (2014), which states that simultaneously and partially the trust level factor

the government has an effect on tax evasion actions by taxpayers. This is possible because the perception of taxpayers will report on the case of the tax mafia and some cases of corruption lead to conflicts of trust of respondents as taxpayers of tax employees and government officials. If the taxpayer's trust in the government increases, the practice of tax evasion will be increasingly

Decreased and resulted in increased tax revenues. This is in line with the research conducted by Yeni (2013) stating that the existence of trust in taxpayers with the government increases voluntary tax compliance and reduces tax evasion. In addition, the results of this study indicate similarities with the research reported by Mohr Ali (2013). Mohd Ali stated that when the community believed in the government's performance, the practice of tax evasion would tend to decline. Correspondingly, Ivanyna's research, Moumouras and Rangazas (2010), also stated that corrupt governance greatly influences the intention of citizens to pay taxes. Thus the disobedience of taxpayers in the scope of the Kebayoran Lama Market in paying taxes is also influenced by the low level of trust of taxpayers towards the government.

Effects of the Society's Social View on the Practice of Tax Evasion

Based on the results of hypothesis testing shows that the variable social outlook positively influences the practice of tax evasion, seen from the significant level of 0.012 (less than 0.05 ) and count smaller than t table. This indicates that the social outlook is getting higher, it will affect the practice of tax evasion significantly. These findings are in line with the research reported by Maria (2014), which states that simultaneously and partially social factors influence tax evasion by taxpayers. This finding is also in accordance with previous research conducted by Demir (2011) by taking samples of taxpayers in Turkey.Karlinsky, et al. (2014) also reported the same results that one's intention to embezzle taxes was influenced by social views. The results of this study also further support the validity of the social learning theory described by Bandura (2014). Bandura states that one can learn through direct observation and experience, so that if the majority of the public embezzles taxes it will affect taxpayers in the community to further embezzle taxes. 


\section{CONCLUSIONS AND SUGGESTIONS}

\section{A. Conclusion}

This study aims to determine the effect of Taxpayer Trust and the Society's Social View on Tax Evasion. The respondents of this study were 100 individual taxpayers who were in the Kebayoran Lama Market. Based on the data that has been collected and the tests that have been carried out on the problem, it can be concluded as follows: From the results of the discussion and data analysis in the previous chapter the variables of environmental advertising have a significant effect on the purchasing decisions of bottled water in Ades. This is indicated by the $\mathrm{t}$-value of 5.253 which is greater than $\mathrm{t}$ table of 1.96 , which means that the purchasing decision can be influenced by one of them is the go green factor with product innovation that is environmentally friendly and invites the public to care. Environment.

The trust of taxpayers to the government has a significant negative effect on the practice of tax evasion. This proves that the lower the level of trust in the taxpayer, the more it increases the practice of tax evasion.

In this study shows that social views have a significant positive effect on the practice of tax evasion. This proves that the higher the social outlook, the more it increases the practice of tax evasion.

\section{B. Implications}

There are several implications or limitations in this study, namely:

1. the chosen observation area is a market area, making people sometimes reluctant to fill out questionnaires and take a long time to make the research stagnate.

2. The research sample only focuses on Individual Taxpayers who are in the market scope of Kebayoran Lama and do not enter the Corporate Taxpayer because tax reporting for Corporate Taxpayers is represented by company couriers.

\section{Suggestion}

Based on the results of the analysis and discussion that has been explained and the conclusions that have been described previously, the researcher wants to give some suggestions that can be used as material input or consideration for interested parties as follows:

1. Directorate General of Taxes

The government as the highest institution mandated to manage existing tax funds must further improve performance, quality, quality, discipline and integrity that are related to the morals demanded by each Directorate General of Taxes by being honest and clean from despicable actions and always prioritizing interests Country.

2. Government

The government must be better at overseeing, accommodating, distributing and processing existing tax funds,

\section{REFERENCE}

Agnar Sandmo. (2005). The Theory of Tax Evasion: A Retrospective View. National Tax Journal, Vol LVIII, No.4 December 2005.

Agus Nugroho Jatmiko. (2006). Pengaruh Sikap Wajib Pajak dan Pelaksanaan Sanksi Denda, Pelayanan Fiskus dan Kesadaran Perpajakan terhadap Kepatuhan Wajib Pajak. Tesis. Program Studi Magister Akuntansi Universitas Diponegoro.

Angelina, Maria dan Yenni. (2014). "Pengaruh Pandangan Sosial, Usia, dan Kepercayaan Kepada Pemerintah Terhadap Praktik Penggelapan Pajak di Surabaya”. Jurnal Tax \& Accounting Review, Universitas Kristen Petra, Vol 4, No1.

Ardyaksa, Theo dan Kiswanto. (2014). “Pengaruh Keadilan, Tarif Pajak,Ketepatan Pengalokasian, Kecurangan, Teknologi dan Informasi Perpajakan terhadapTax Evasion”. Accounting Analysis Journal, Unniversitas Negri Semarang,Vol 3 No.4

Benk, Serka7n dkk. (2015). "Perception of tax evesion as a crime in Turkey”.Jurnal of Money Laundering, Unniversitas of Queensland,Vol 18 No 1.

Demir, Ihsan Cemil. (2011). The Role Of Selected Economic and Non-Economic Factors on Tax Evasion : An Empirical Inspection.

Devi Nur Cahya Ningsih dan Devy Pusposari. (2015). Determinan Persepsi Mengenai Etika atas penggelapan Pajak (Tax Evasion). Jurnal Ilmiah Mahasiswa FEB, Vol.3, No.1.

Direktorat Jendral Pajak Kementrian Keuangan. Pengertian Tax Amnesty: Amnesty Pajak 2016. Diakses dari http://www.lembagapajak.com/2016/07pengertian-pengampunan-pajak-tax-amnesty-adalah.html tanggal 11 September 2016.

Elmiza, Mesri dkk. (2014). “ Pengaruh Keadilan, Sistem Perpajakan dan Diskiminasi Terhadap Presepsi Wajib Pajak Mengenai Etika Penggelapan Pajak (Tax Evasion)”. E-Journal Universitas Bung Hatta, Jakarta, Vol 4 No 1

Enste, H. Dominik \& Schendik, Frederick, Shadow Economies: Size, Causes and Consequences, Journal of Economic Literature, Vol. XXXVIII March 2000, pp 77-114

Erly Suandy.(2008). Perencanaan Pajak, Ed 4. Jakarta : Salemba Empat. 
Ghozali, I. (2009). Aplikasi Analisis Multivariate dengan Program SPSS. Semarang: Badan Penerbit Universitas Diponegoro.

Hammar, H., S. C. Jagers., dan K.Nordblom. (2005). “Tax Evasion and the Importance of Trust”. Working Paper in Economic, Swedia, no. 179.

Harold Kelley.(1973). The Process of Causal Attribution. American Psychologist February 1973

Huslin, Daniel dan Ngadiman. (2011). Pengaruh Sunset Policy, Tax Amnesty, dan Sanksi Pajak Terhadap Kepatuhan Wajib Pajak. Jurnal Akuntansi. Vol XIX, No.02, Mei 2015:225-241.

Imelda, Bona. (2014). “Analisa Faktor-Faktor Yang Mempengaruhi Kepatuhan Wajib Pajak Orang Pribadi (Studi PAda Kantor Pelayanan Pajak Pratama Semarang)”. Skripsi.Semarang: Fakultas Ekonomi dan Bisnis Universitas Diponegoro.

Ivanyna, Maksym, Alexandros Mourmoras and Peter Rangazas. (2010). The Culture of Corruption, Tax Evasion and Optimal Tax Policy. International Monetary Fund WP/10/xx.

Mardiasmo.(2011). Perpajakan Edisi Revisi 2011. Yogyakarta: Penerbit Andi.

Maria Angelia Sutiono dan Yenni Mangoting. (2014). Pengaruh Pandangan, Usia dan Kepercayaan kepada Pemerintah terhadap Praktik Penggelapan Pajak di Surabaya. Tax and Accounting Review, Vol.4, No.1.

Marina.(2015). Pengaruh Risiko Persepsian dan Risiko Kinerja terhadap Intensi Mengadopsi e-Filling. Skripsi. Fakultas Ekonomi dan Bisnis Universitas Mercu Buana.

McGee, Robert W dkk. (2008). “ A Comparative Study on Perceived Ethics of Tax Evasion: Hong Kong vs the United States”. Journal of Business Ethics, no 77.

McGee, Robert dkk. 2009. " Presenting the Dimensionality of An Ethics Scale pertaining to Tax Evasion ". Journal of Legal, Ethical and Regulatory Issues, 23

Mughal, Muhammad Muazzam and Muhammad Akram. (2014). Reasons of Tax Avoidance and Tax Evasion: Reflections from Pakistan. Journal of Economics and Behavioral Studies Vol. 4 No. 4

Nazaruddin, Ietje dan Agus Tri (2016).Analisis Statistik dengan SPSS. Yogyakarta: Danisa Media

Rachmadi, Wahyu. (2014). “Faktor-Faktor Yang Mempengaruhi Persepsi Wajib Pajak Orang Pribadi Atas Perilaku Penggelapan Pajak (Studi Empiris Pada Wajib Pajak Terrdaftar di KPP Pratama Semarang Candsari)”. Skripsi.Universitas Diponegoro.

Rahman, I. S. (2013). "Pengaruh Keadilan, Sistem Perpajakan, Diskriminasi, dan Kemungkinan Terdeteksinya Kecurangan Terhadap Persepsi Wajib Pajak Mengenai Etika Penggelapan Pajak (Tax Evasion)”.'Skripsi. Jakarta: Fakultas Ekonomi dan Bisnis Universitas Islam Negeri Syarif Hidayatullah.

Salim, Gustina. (2016). "Pengaruh Kepercayaan Wajib Pajak, Pandangan Sosial Masyarakat, dan Sistem Perpajakan tehadap Praktik Penggelapan Pajak. Skripsi. Program Studi Akuntansi Universitas Mercubuana.

Santoso, Urip \& Justina, Setiawan.(2009) Tax amnesty dan Pelaksanaanya di Beberapa Negara: Perspektif Bagi Pebisnis Indonesia, Kopertis, Volume 11 No. 2.

Siahan, Marihot P. (2010). Hukum Pajak Elementer.Yogyakarta. Penerbit: Graha Ilmu.

Suminarsasi, W. dan Supriyadi. (2011). "Pengaruh Keadilan, Sistem Perpajakan,dan Diskriminasi Terhadap Persepsi Wajib Pajak Mengenai Etika Penggelapan Pajak (Tax Evasion)”. Thesis. Yogyakarta: Universitas Gadjah Mada.

Tarmidi Deden, Waluyo TEKUN: Jurnal

Telaah Akuntansi dan Bisnis 2014,Faktor-Faktor yang Mempengaruhi Kepatuhan Pajak, Dengan Pendekatan Perilaku dan Etika (Studi Empiris Pada Perusahaan PMA Yang Terdaftar Di Kanwil DJP Jakarta Khusus)

Theresia Woro Damayanti, dkk.(2015). The Role of Taxpayer's Perception of the Government and Society to Improve Tax Compliance. Accounting and Financial Research. Vol. 4, No. 1.

Undang - Undang Republik Indonesia Nomor 11 Tahun 2016 Tentang Pengampunan Pajak. Diakses dari http:www.jdih.kemenkeu.go.id/fullText/2016/11TAHUN20 16.pdf

Wicaksono, Muhammad. (2014). "Pengaruh Persepsi Sistem Perpajakan, Keadilan Pajak, Diskriminasi Pajak Dan Pemahaman Perpajakan Terhadap Perilaku Penggelapan Pajak (Studi Empiris Pada Wajib Pajak Orang Pribadi Terdaftar Di Kpp Pratama Purworejo)'”.Skripsi.Universitas Diponegoro Semarang: 2012. Tidak dipublikasikan.

Widarto, Edwin. (2013). “ Faktor-Faktor Yang Mempengaruhi Kemauan Untuk Membayar Pajak Pada Usaha Kecil dan Menengah (UKM) Di Surabaya. Tesis.Fakultas Bisnis Universitas Katolik Widya Mandala. 